\title{
Expansion of agricultural oasis in the Heihe River Basin of China: Patterns, reasons and policy implications
}

\author{
Wei Song ${ }^{\mathrm{a}, *}$, Ying Zhang ${ }^{\mathrm{b}}$ \\ ${ }^{a}$ Key Laboratory of Land Surface Pattern and Simulation, Institute of Geographic Sciences and Natural Resources Research, Chinese Academy of Sciences, Beijing 100101, China
}

${ }^{\mathrm{b}}$ Chinese Academy of Surveying and Mapping, 28 Lianhuachi West Road, Haidian District, Beijing 100830, China

\section{A R T I C L E I N F O}

\section{Article history:}

Received 11 March 2015

Received in revised form 17 June 2015

Accepted 11 August 2015

Available online 24 August 2015

\section{Keywords:}

Agricultural oasis

Land-use change

Driving forces

Panel data model

The Heihe River Basin

\begin{abstract}
A B S T R A C T
The Heihe River Basin (HRB) is the second largest inland river basin in the arid region of northwestern China. An agricultural oasis is a typical landscape in arid regions providing precious fertile soil, living space and ecological services. The agricultural oasis change has been one of the key issues in sustainable development in recent decades. In this paper, we examined the changes in the agricultural oasis in HRB and analyzed the socio-economic and climatic driving forces behind them. It was found that the agricultural oasis in HRB expanded by $25.11 \%$ and $14.82 \%$ during the periods of $1986-2000$ and 2000 2011, respectively. Most of the newly added agricultural oases in HRB were converted from grassland (40.94\%) and unused land (40.22\%). The expansion in the agricultural oasis mainly occurred in the middle reaches of HRB, particularly in the counties of Shandan, Minle, Jinta and Jiuquan city. Changes in the rural labor force, annual temperature and precipitation have significant positive effects on agricultural oasis changes, while the ratio of irrigated agricultural oases has significant negative effects on agricultural oasis changes. The agricultural oasis expansion in HRB is the combined effect of human activity and climate change.
\end{abstract}

(c) 2015 Elsevier Ltd. All rights reserved.

\section{Introduction}

Arid and semi-arid regions cover more than $30 \%$ of the land on the earth's surface (Okin et al., 2006) and 22\% of the land area in China (Bai et al., 2014). An oasis is a unique intrazonal landscapes existing within arid and semi-arid regions, which allows flourishing vegetation and human settlement due to a stable water supply (Ling et al., 2013). Although an oasis covers less than 5\% of the total area in arid and semi-arid regions in China, it holds more than $90 \%$ of the population and $95 \%$ of social wealth in these regions (Wang et al., 2008). An oasis not only provides precious fertile soil and living space for human beings in the barren desert, but also regulates the regional climate by the vegetation and water resources within it. Therefore, the oasis ecosystem directly influences the environmental and social security in arid and semi-arid regions. The oasis change has been one of the key issues in the sustainable development in recent decades (Cheng et al., 2006).

An agricultural oasis is defined as cultivated land that can be irrigated by human activities (Bai et al., 2014). Since an agricultural oasis can provide the necessary grain for population growth, it plays a vital role in sustainable social development. After the

\footnotetext{
* Corresponding author.

E-mail address: songw@igsnrr.ac.cn (W. Song).
}

foundation of the People's Republic of China in 1949, as well as the implementation of reform and the opening-up policy in 1978, the economy in China developed rapidly, inducing the evolution in agricultural oases. The evolution of agricultural oases has two opposite processes: oasification and desertification (Li et al., 2006; Su et al., 2007; Zhang et al., 2003). Agricultural oasification usually means the expansion of an agricultural oasis, i.e. converting the desert to an agricultural oasis under the combined effects of human activities and climate change (Xie et al., 2014). Desertification usually means the degradation of an agricultural oasis, i.e. converting an agricultural oasis into a desert (Chen et al., 2014; Liu et al., 2010b; Pan and Li, 2013; Zhang et al., 2008).

The expansion of an agricultural oasis can increase the total crop yields and promote humans' well-being to some degree. However, the scale of an agricultural oasis is not necessarily "the larger the better" (Ling et al., 2013). Water is a vital limiting factor for sustainable crop production and social development in arid and semi-arid regions (Jia et al., 2004). The expansion of an agricultural oasis will inevitably increase the water demand due to irrigation (Jiang et al., 2015; Ma et al., 2015). When the scale of an agricultural oasis exceeds the carrying capacity of water resources, the stability of an agricultural oasis will be challenged, inducing severe ecological and environmental problems (Lu et al., 2003; Zhang et al., 2003). The decline of several ancient agricultural oasis 
civilizations (e.g. ancient Babylon) is partly related to the irrational expansion of agricultural oases. Therefore, examining the changes in agricultural oases and discerning the driving forces behind them are urgently needed for controlling irrational expansion of agricultural oases.

Currently, research related to oasis change has focused on four aspects: analyzing the land use patterns in oasis agricultural region (Bai et al., 2014; Guo et al., 2008; Hu and Li, 2014; Wang et al., 2014), discerning the relationship between agricultural oasis change and water resources (Misak et al., 1997; Siebert et al., 2007), assessing the ecological effects of agricultural oasis changes (Su et al., 2007; Zhang et al., 2014), and discussing the suitable scale of an agricultural oasis (Ling et al., 2013). Although great efforts have been made in the field of oasis change, less attention has been paid to identify the factors driving oasis change. In the limited literature that analyzes the driving forces of agricultural oasis change, a qualitative analysis has been frequently adopted but it cannot accurately identify the key driving forces.

To fill the knowledge gap, we examined the changes in the agricultural oasis in the Heihe River Basin (HRB), the second largest inland river basin in Northwest China, and quantitatively discerned the driving forces behind them using a panel data model. To be specific, the aims of this paper are to: (1) examine the spatial-temporal patterns of agricultural oasis changes in HRB from 1986 to 2011; (2) identify the conclusive factors driving agricultural oasis changes; and (3) discuss the feasible policies controlling the irrational expansion of agricultural oasis.

\section{Study area and data sources}

\subsection{Study area}

HRB is located in northwestern China $\left(38^{\circ} \mathrm{N}-42^{\circ} \mathrm{N}, 98^{\circ} \mathrm{E}-101^{\circ} \mathrm{E}\right)$, covering an area over 143.29 thousand kilometers (Fig. 1). HRB is a typical arid region in China. The annual average precipitation is about $37 \mathrm{~mm}, 45 \mathrm{~mm}$ and $55 \mathrm{~mm}$ according to the monitoring result of local meteorological stations of Ejin, Guaizihu and Dingxin in HRB, while the annual average evaporation exceeded $3000 \mathrm{~mm}$ (Xiao et al., 2015).

The Heihe River is the second longest inland river in the arid region of northwestern China. The total length of the Heihe River reaches $821 \mathrm{~km}$ (Huai et al., 2014). According to the location of

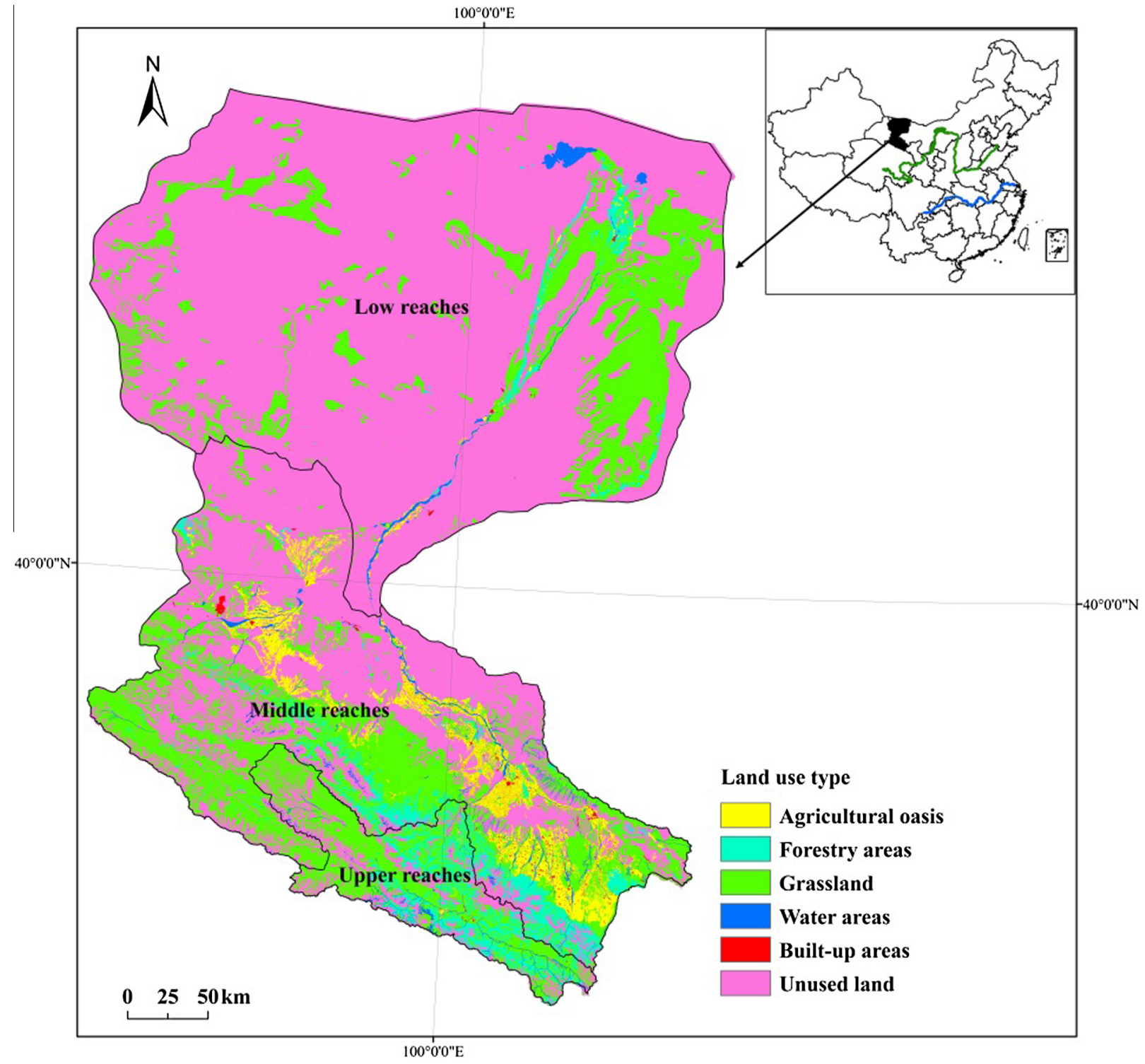

Fig. 1. The location and land use patterns of the Heihe River Basin in 1986. 
Table 1

Selected factors driving agricultural oasis expansion and their connotations.

\begin{tabular}{|c|c|}
\hline Driving forces & Connotation \\
\hline Rural labor force & Number of rural population whose age is between 16 years old and 60 years old and frequently participate agricultural production \\
\hline Agricultural machinery & $\begin{array}{l}\text { The sum of agricultural machinery power, including cultivation machinery, irrigation and drainage machinery, harvest machinery, farm } \\
\text { transporting mechanism etc. }\end{array}$ \\
\hline Irrigation ratio & The area ratio of irrigated cultivated land to total cultivated land \\
\hline Plantation structure & The ratio of the grain-sown area to agricultural crop sown area \\
\hline Grain yield per unit & The yield of grain crop per unit areas of land cultivation \\
\hline Annual precipitation & The total precipitation in a year \\
\hline Annual temperature & The average temperature in a year \\
\hline Grain-for-green policy & A dummy variable. Before grain-for-green policy is launched, it is valued as 0 . After grain-for-green policy is launched, it is valued as 1 \\
\hline
\end{tabular}

hydrometric stations of Yingluoxia and Zhengyixia, the Heihe River is divided into upper, middle and lower reaches. The upper reaches of HRB are runoff formation areas where cold desert accounted for $22 \%$ of the total area. The middle reaches of HRB are runoff-using areas where most of the agricultural oasis, population and GDP (gross domestic product) are concentrated. The lower reaches of HRB are a runoff-fade area with a huge evaporation capacity.

The oasis strip in HRB plays a vital ecological role in northwestern China. In past decades, with the continuous expansion of the agricultural oasis, the demand for irrigation water has significantly increased, which has triggered a great deal of ecological and environmental problems.

\subsection{Data sources}

The data that we used for analyzing agricultural oasis changes in HRB were based on three maps of land use in 1986, 2000 and 2011. The scale of these maps is 1:100,000. The land use maps, interpreted from Thematic Mapper satellite images by the human-machine interactive approach, were acquired from the Western Data Center in China (http://westdc.westgis.ac.cn/). The average interpretative accuracy of the land use maps is over $95 \%$ (Liu et al., 2014, 2005, 2010a). The land use was divided into six primary types (cultivated land, forestry area, grasslands, water areas, built-up area, and unused land) and 25 sub-classes (Deng et al., 2006, 2010).

The precipitation data in 1986, 2000 and 2011 in HRB were collected from the China Meteorological Data Sharing Service System (http://cdc.cma.gov.cn/home.do). The socio-economic data including population, income, grain yield, labor, etc., were collected from the local statistic bureaus in HRB.

\section{Methodology}

\subsection{Selection of factors driving agricultural oasis change}

According to the definition, an agricultural oasis refers to the irrigated cultivated land in arid and semi-arid regions (Bai et al., 2014). However, because of the lack of spatial irrigation data, we cannot identify the irrigated cultivated land in HRB. In consideration of the high irrigation rate of an agricultural oasis, we defined the cultivated land in HRB as the agricultural oasis. The driving forces were selected in accordance with previous researches (Amuti and Luo, 2014; Cheng et al., 2006; Deng and Bai, 2014; King and Thomas, 2014; Xie et al., 2014; Zhao and Chang, 2014) and the personal knowledge of authors of this paper. The first independent variable we selected is the rural labor force (Table 1). The existence of an agricultural oasis firstly depends on the cultivation of the rural labor force. In general, more rural labor forces are needed to cultivate more agricultural oases. With the development of the economy and agricultural techniques, more and more agricultural machinery has been utilized in agricultural production. The use of agricultural machinery can substitute the rural labor force to some degree, and thus influences the scale of an agricultural oasis. Here, we selected the input of agricultural machinery per unit as an independent variable.

An agricultural oasis exists in arid or semi-arid regions where the water resource is a vital limiting factor (Jin et al., 2014). The abundance or shortage of water resources could determine the scale of the agricultural oasis to some degree. Here, we utilized the ratio of irrigated agricultural oases to reflect the limitation of water resources in agricultural production. The increasing demand for grains or household income can be solved by either the expansion of an agricultural oasis or the increase in grain yield per unit. Therefore, grain yield per unit was selected as an independent variable. In addition, not all the agricultural oases was sown for grain. For the comparative returns, cash crops were planted more than ever in HRB. Changes in plantation structure could be a potential factor influencing the changes in an agricultural oasis. Here, we selected the ratio of the grain-sown area to represent the plantation structure.

The Chinese government launched several land use policies at the end of 1990s, which deeply influenced the land-use changes in China (Deng et al., 2015a; Song, 2014; Song and Liu, 2014; Song and Pijanowski, 2014). One of the land use policies is the grain-for-green policy, which aims to return deep sloping cultivated land to forestry or grassland. Since the policy directly related to the conversion of agricultural oases and grassland or forestry areas, we established a dummy variable of the grain-for-green policy to analyze its influence on agricultural oasis change. In spite of the influence of human activity, climate change has been identified as a vital factor driving changes in land use and water resources (Kenabatho et al., 2012; Kusangaya et al., 2014; Nutter et al., 2013). In this paper, we selected the annual average precipitation and temperature to describe the climate change in HRB.

\subsection{Panel data model}

In this paper, we try to quantitatively analyze the driving forces of agricultural oasis changes. Given there are only three time series of agricultural oases interpreted from satellite images, the regular regression analysis is strongly limited because of the insufficient samples. However, HRB is composed of about ten counties or cities. If the spatial data at the county level were sufficiently utilized, there would be enough samples to perform regression analysis.

The panel data model can arrange data in spatial and temporal dimensions. Therefore, it effectively increases the number of samples through repeated observation of the same section. It also controls the individual differences (unobserved effect) by setting dummy variables that can better integrate the observed values of different sections at multiple time periods (Seto and Kaufmann, 2003). In this way, the model improves the degree of freedom, 
Table 2

The Hausman test of parametric estimation models.

\begin{tabular}{|c|c|c|c|c|}
\hline & \multicolumn{2}{|c|}{ Coefficients } & \multirow[b]{2}{*}{$\begin{array}{l}(b-B) \\
\text { Difference }\end{array}$} & \multirow[b]{2}{*}{$\begin{array}{l}\text { Sqrt }\left(\operatorname{diag}\left(V_{b}-V_{B}\right)\right) \\
\text { S.E. }\end{array}$} \\
\hline & (b) & (B) & & \\
\hline Rural labor force & 0.8668 & 0.8212 & 0.0455 & 0.5413 \\
\hline Agricultural machine & -0.1279 & -0.0423 & -0.0856 & 0.1576 \\
\hline Irrigation ratio & -0.4241 & -0.4525 & 0.0283 & 0.2081 \\
\hline Plantation structure & 0.0243 & -0.0403 & 0.0646 & 0.1644 \\
\hline Grain yield per unit & -0.0149 & -0.0706 & 0.0558 & 0.2873 \\
\hline Annual precipitation & 0.9223 & 0.6032 & 0.3191 & 0.3999 \\
\hline Annual temperature & 0.8656 & 0.6737 & 0.1919 & 0.2987 \\
\hline Grain-for-green policy & -0.3373 & -0.2397 & -0.0975 & 0.4271 \\
\hline
\end{tabular}

Notes: $\chi^{2}(8)=(b-B)^{\prime}\left[\left(V_{b}-V_{B}\right)^{(-1)}\right](b-B)=1.17$; Prob $>\chi^{2}=0.9969$.
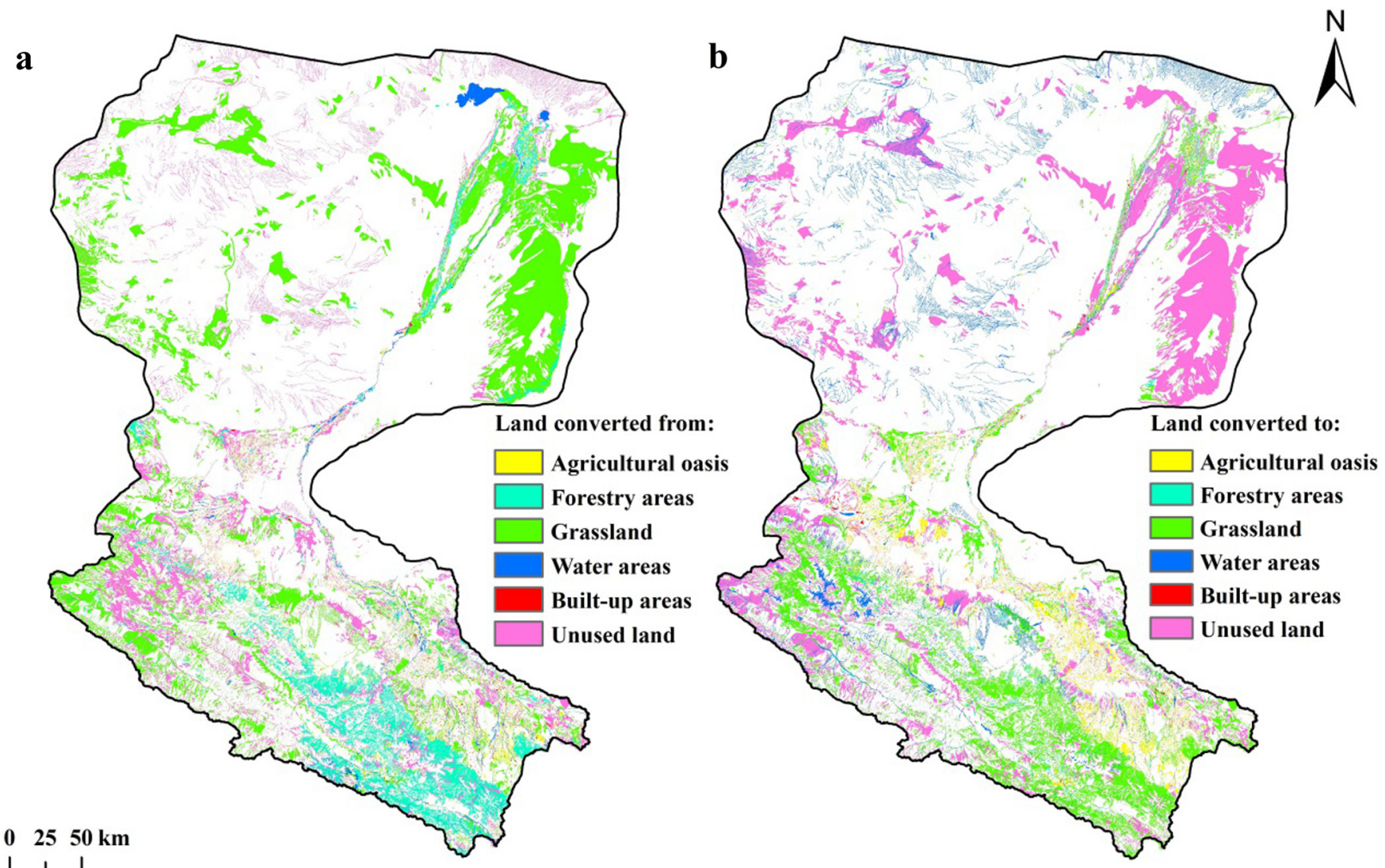

Fig. 2. Land-use changes in the Heihe River Basin, 1986-2000.

reduces the co-linearity of the explanatory variables, and thus describes well the dynamics in agricultural oasis changes. The model formula is (Seto and Kaufmann, 2003):

$y_{i t}=\alpha_{i}+\beta_{i} x_{i t}+u_{i t}$

where $y_{i t}$ is the value of the dependent variable on section $i$ at time $t ; \alpha_{i}$ is the intercept on section $i ; x_{i t}$ is the value of the independent variable on section $i$ at time $t ; \beta_{i}$ is the $k \times 1$ order coefficient vector on section $i ; \mu_{i}$ is an error term on section $i$.

For individual $i, a_{i}$ represents the influencing factors that did not change with time. Under most circumstances, these factors cannot be directly observed or quantitatively valued, which were defined as individual effects. There are two different approaches to address the individual effects: the fixed effect model and random effect model. In the fixed effect model, the individual difference was reflected in the interpreted item of each individual. However, the random effect model assumed that the interpreted item of all individuals is the same. The individual differences are mainly reflected in the random disturb item. Through the Hausman test (Table 2), the random effect model was selected to analyze the driving forces of agricultural oasis change.

\section{Result}

\subsection{Land use patterns in HRB in 1986}

Unused land comprised the largest proportion (67.99\%) of HRB in 1986. The proportion of grassland was also high, reaching $23.08 \%$ (Fig. 1). However, the proportions of the agricultural oasis, forestry areas, water areas and built-up areas are as low as $3.45 \%$, $4.11 \%, 1.06 \%$ and $0.31 \%$, respectively. Gobi is the primary land use type within unused land, contributing to $50.32 \%$ of the total. The 

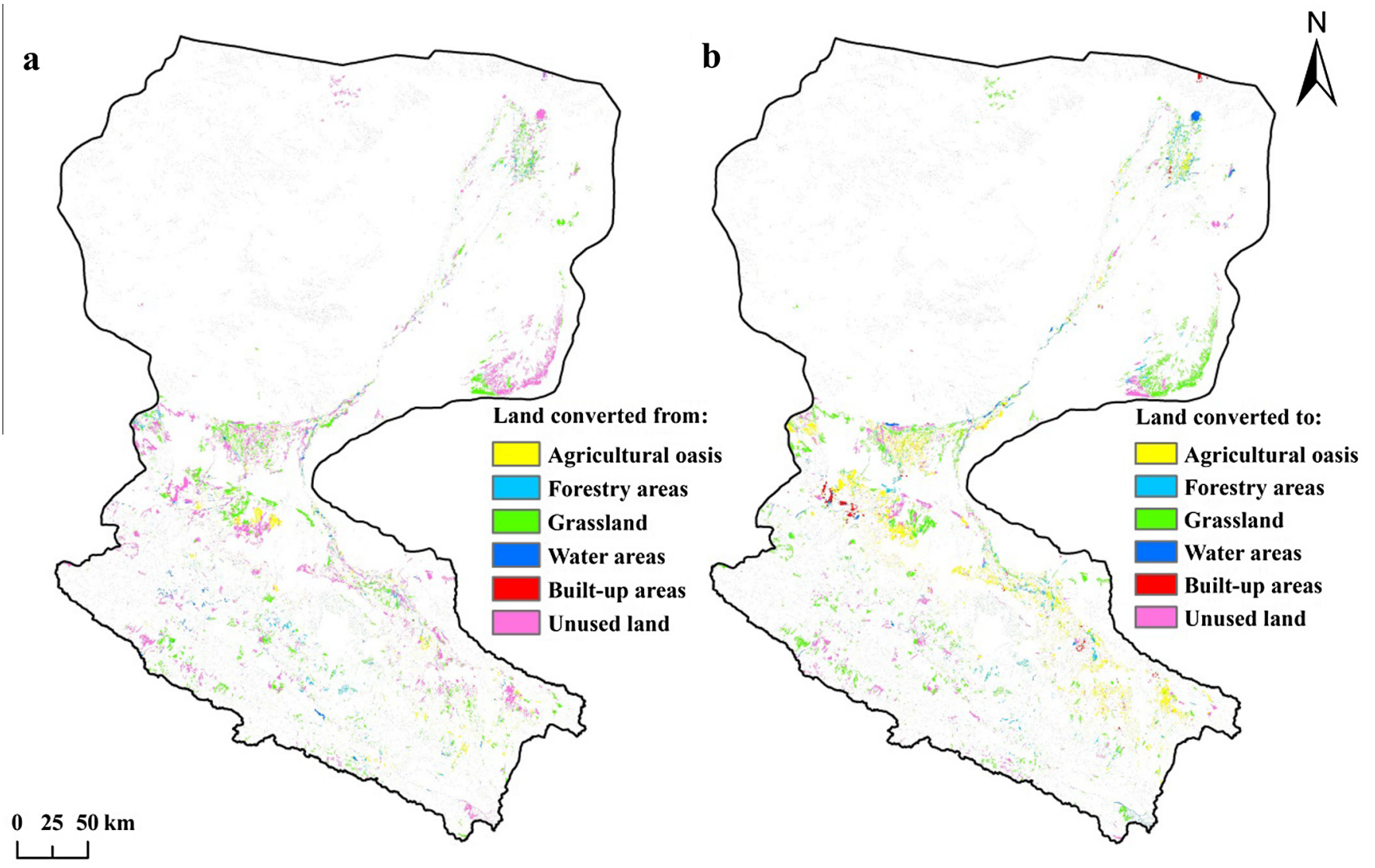

Fig. 3. Land-use changes in the Heihe River Basin, 2000-2011.

Table 3

Land use conversions in agricultural oasis, 1986-2000 and 2000-2011.

\begin{tabular}{lccccc}
\hline & \multicolumn{2}{l}{$\begin{array}{l}\text { Gained agricultural oasis } \\
\left(\mathrm{km}^{2}\right)\end{array}$} & & \multicolumn{2}{l}{$\begin{array}{l}\text { Lost agricultural oasis } \\
\left(\mathrm{km}^{2}\right)\end{array}$} \\
\cline { 2 - 3 } \cline { 5 - 6 } \cline { 5 - 6 } & $1986-2000$ & $2000-2011$ & & $1986-2000$ & $2000-2011$ \\
\hline Forestry areas & 152.73 & 34.55 & & 23.38 & 32.1 \\
Grassland & 847.77 & 433.42 & & 251.57 & 166.61 \\
Water areas & 134.01 & 37.15 & & 54.05 & 13.28 \\
Built-up areas & 213.53 & 17.54 & & 105.33 & 85.86 \\
Unused land & 497.78 & 760.91 & & 170.42 & 69.02 \\
Total & 1845.81 & 1283.57 & 604.75 & 366.88 \\
\hline
\end{tabular}

bare rock and sandy land also take up $23.77 \%$ and $13.76 \%$ of unused land.

The distribution of the six land use types showed obvious reaches in variation. The area proportions of upper, middle and lower reaches in HRB are $7.01 \%, 59.64 \%$ and $33.35 \%$, respectively. However, $96.58 \%$ of the agricultural oasis and $92.73 \%$ of built-up areas concentrated in middle reaches, while $72.44 \%$ of unused land distributed in the lower reaches. The proportions of forestry areas, grassland and water areas in middle reaches are also as high as $48.25 \%, 44.36 \%$ and $49.50 \%$, respectively. Nevertheless, the proportions of the three land use types are all lower than the area proportions of middle reaches (59.64\%).

\subsection{Land-use changes in $H R B$}

The most significant land-use changes from 1986 to 2000 in HRB were the expansion of agricultural oases (25.11\%) and water areas (206.06\%), and the shrinkage of forestry areas (78.00\%) and grassland (27.30\%) (Fig. 2). In addition, built-up areas in HRB significantly decreased by $19.02 \%$ from 1986 to 2000 in spite of the rapid growth of the population and economy. Unused land also rapidly expanded by $9.60 \%$ during this period. In the upper reaches of HRB, the most significant land-use changes are the expansion of the agricultural oasis (98.73\%) and the shrink of forestry areas $(-87.17 \%)$. In the middle reaches of $\mathrm{HRB}$, water areas significantly expanded by $162.02 \%$ while forestry areas decreased by $-78.80 \%$. In the lower reaches of HRB, water areas and built-up areas expanded by $359.72 \%$ and $56.01 \%$, respectively while grassland decreased by $84.29 \%$.

The agricultural oasis continued with positive changes in area, with an increase rate of $14.82 \%$ from 2000 to 2011, while the five other land use types all presented opposite trends (Fig. 3) compared to the previous period. Forestry area, grassland and built-up areas changed from negative trends from 1986 to 2000 to positive trends from 2000 to 2011 , with increase rates of $11.57 \%, 0.95 \%$ and $47.54 \%$, respectively. Water areas and unused land ceased the positive changes in the previous period, and decreased by $0.86 \%$ and $1.99 \%$ from 2000 to 2011, respectively. Although the agricultural oasis increased at the whole HRB, it decreased by $17.37 \%$ in the upper reaches of HRB. In middle reaches of HRB, built-up areas significantly increased by $45.63 \%$ while water areas and unused land decreased by $3.08 \%$ and $4.28 \%$, respectively. In the low reaches of HRB, the agricultural oasis and built-up areas expanded by $14.83 \%$ and $47.69 \%$, respectively while unused land decreased by $1.49 \%$. As a whole, the predominant land-use changes during this period were the expansion of the agricultural oasis and built-up areas.

\subsection{Expansion of agricultural oasis in HRB}

\subsubsection{Conversions in agricultural oasis}

The agricultural oasis in HRB changed from $4942.59 \mathrm{~km}^{2}$ in 1986 to $6183.67 \mathrm{~km}^{2}$ in 2000 , with an expansion rate of $25.11 \%$ (annual rate of 1.79\%). In the subsequent period (2000-2011), 

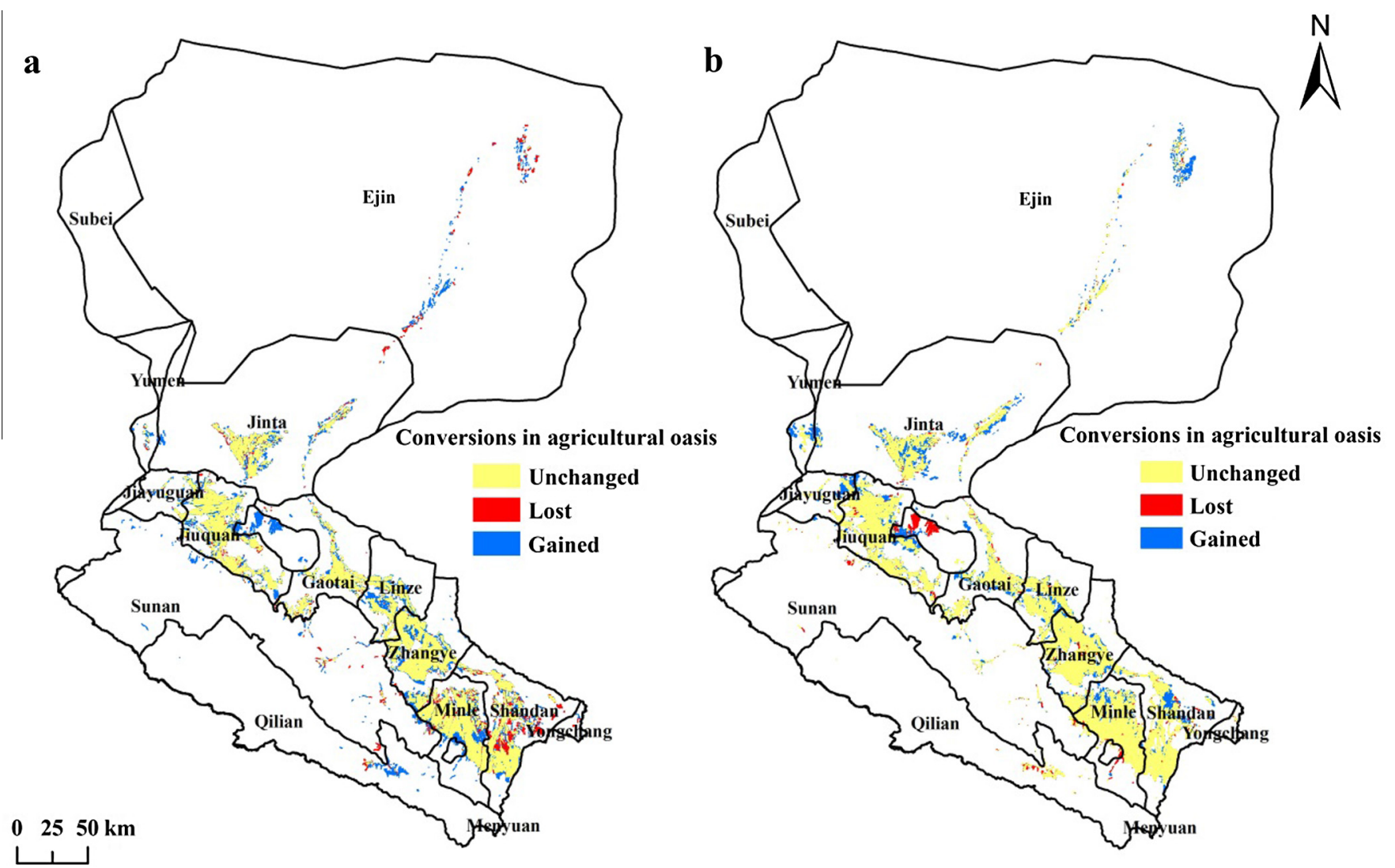

Fig. 4. Expansion and shrinkage of agricultural oasis in Heihe River Basin, 1986-2000 (a) and 2000-2011 (b).

the agricultural oasis increased from $6183.67 \mathrm{~km}^{2}$ in 2000 to $7100.14 \mathrm{~km}^{2}$ in 2011 , with an increase rate of $14.82 \%$ (annual rate of $1.35 \%$ ). The agricultural oasis expanded continuously during the two periods, while the annual expansion speed decreased over time.

Drastic conversions existed in the agricultural oasis in HRB. A total of $1845.81 \mathrm{~km}^{2}$ of other land use types were converted into an agricultural oasis from 1986 to 2000 (Table 3), among which grassland contributed to $45.93 \%$, unused land $26.97 \%$, built-up areas $11.57 \%$, forestry areas $8.27 \%$ and water areas $7.26 \%$. The reclamation of grassland was the primary approach to generate new agricultural oases. The agricultural oasis loss was more moderate compared to the expansion of agricultural oases. A total of $604.75 \mathrm{~km}^{2}$ of agricultural oases were converted into other land use types during the period 1986-2000 (Table 3). Most of the lost agricultural oases were converted into grassland $(41.60 \%)$, followed by unused land (28.18\%), built-up areas (17.42\%), water areas (8.94\%) and forestry areas (3.87\%). The conversions from agricultural oasis to grassland were the leading conversions in agricultural oasis change.

Similar conversions occurred in the latter period (2000-2011). A total of $1283.57 \mathrm{~km}^{2}$ of other land use types were converted into agricultural oases, while only $366.88 \mathrm{~km}^{2}$ of agricultural oases were converted into other land use types (Table 3 ). Unused land became the main contributor (59.28\%) of newly added agricultural oases. Grassland changed to the second contributor (33.77\%), followed by forestry areas (2.69\%), water areas (2.89\%) and built-up areas $(1.37 \%)$. However, grassland was still the primary destination (45.41\%) of the lost agricultural oases, followed by built-up areas $(23.40 \%)$, unused land (18.81\%), forestry areas (8.75\%) and water areas $(3.62 \%)$

\subsubsection{Spatial patterns of agricultural oasis expansion}

The expansion and shrinkage of agricultural oases mainly occurred in the counties of the middle reaches (Fig. 4). The expansion of the agricultural oasis in the Zhangye municipal district, Minle county, Jiuquan county and Shandan county accounted for $17.60 \%, 14.02 \%, 13.88 \%$ and $12.05 \%$ of total expansion, respectively. The counties of Shandan, Minle, Jinta and Jiuquan city experienced severe agricultural oasis loss, accounting for 26.99\%, $15.93 \%$, $11.95 \%$ and $10.45 \%$ of total loss, respectively.

In the latter period, agricultural oasis expansion was still concentrated in the same four counties with the former period. However, the orders of the four counties in agricultural oasis expansion slightly changed. Jinta instead of Zhangye municipal district changed to be the first contributor of agricultural oasis expansion, accounting for $18.04 \%$ of total, followed by Jiuquan (15.74\%), Shandan (11.75\%) and Zhangye (9.79\%). The agricultural oasis loss at the county level during the period 2000-2011 was a little different from that of 1986-2000. Sunan Yugu changed to the primary region of agricultural oasis loss, accounting for $29.21 \%$ of the total. The agricultural oasis losses were also severe in Jiuquan city (12.95\%), Zhangye municipal district (11.08\%), Minle county (10.08\%) and Shandan county (10.10\%).

\subsection{Driving forces analysis of agricultural oasis expansion}

The significance testing of the panel data model shows that the driving force model is significant at the 0.05 significance level (Prob $>\chi^{2}=0.0000$ ). The $R$ square of the model within groups, between groups and overall level are $0.7560,0.9875$ and 0.9203 , respectively. The fitting precision of the driving force model is satisfactory. 
Table 4

Regression results of random effects model based on panel data.

\begin{tabular}{|c|c|c|c|c|c|}
\hline & Eq. (1) & Eq. (2) & Eq. (3) & Eq. (4) & Eq. (5) \\
\hline Rural labor force & $\begin{array}{l}0.774^{* * * *} \\
-7.69\end{array}$ & $\begin{array}{l}0.914^{* * *} \\
-9.72\end{array}$ & $\begin{array}{l}0.926^{* * *} \\
-9.29\end{array}$ & $\begin{array}{l}0.815^{* * * *} \\
-7.18\end{array}$ & $\begin{array}{l}0.821^{* * * *} \\
-7.21\end{array}$ \\
\hline Agricultural machinery & $\begin{array}{l}-0.319^{* *} \\
(-3.18)\end{array}$ & $\begin{array}{l}-0.111 \\
(-1.06)\end{array}$ & $\begin{array}{l}-0.111 \\
(-1.02)\end{array}$ & $\begin{array}{l}-0.0904 \\
(-0.80)\end{array}$ & $\begin{array}{l}-0.0423 \\
(-0.34)\end{array}$ \\
\hline Irrigation ratio & & $\begin{array}{l}-0.367^{* * *} \\
(-3.35)\end{array}$ & $\begin{array}{l}-0.335^{* *} \\
(-2.62)\end{array}$ & $\begin{array}{l}-0.381^{* *} \\
(-3.25)\end{array}$ & $\begin{array}{l}-0.452^{* *} \\
(-3.27)\end{array}$ \\
\hline Plantation structure & & & $\begin{array}{l}-0.0553 \\
(-0.56)\end{array}$ & $\begin{array}{l}-0.0058 \\
(-0.07)\end{array}$ & $\begin{array}{l}-0.0403 \\
(-0.44)\end{array}$ \\
\hline Grain yield per unit & & & $\begin{array}{l}-0.0278 \\
(-0.29)\end{array}$ & $\begin{array}{l}-0.13 \\
(-1.37)\end{array}$ & $\begin{array}{l}-0.0706 \\
(-0.62)\end{array}$ \\
\hline Annual precipitation & & & & $\begin{array}{l}0.511^{* *} \\
-3.16\end{array}$ & $\begin{array}{l}0.603^{* *} \\
-3.21\end{array}$ \\
\hline Annual temperature & & & & $\begin{array}{l}0.599^{* * *} \\
-4.05\end{array}$ & $\begin{array}{l}0.674^{* * * *} \\
-4.03\end{array}$ \\
\hline Grain-for-green policy & & & & & $\begin{array}{l}-0.24 \\
(-0.97)\end{array}$ \\
\hline Constant term & $\begin{array}{l}7 E-07 \\
0\end{array}$ & $\begin{array}{l}7.3 E-07 \\
0\end{array}$ & $\begin{array}{l}0.000000755 \\
0\end{array}$ & $\begin{array}{l}5.5 E-07 \\
0\end{array}$ & $\begin{array}{l}0.16 \\
-0.9\end{array}$ \\
\hline Observations & 27 & 27 & 27 & 27 & 27 \\
\hline
\end{tabular}

Notes: $t$ statistics in parentheses.

*** $p<0.01$.

${ }^{* * *} p<0.001$.

According to the regression result (Table 4), four independent variables passed the significance testing at the 0.05 significance level: the labor force, ratio of irrigated agricultural oasis, annual temperature and precipitation. The expansion of the agricultural oasis in HRB is the combined effect of human activity and climate change.

As expected, the rural labor force has a positive influence on the changes in agricultural oases. The continuous population growth in HRB has induced a sustained growth in rural labor forces. For example, the rural labor forces in Gaotai County increased to 55,600 people in 2011 from 53,900 in 2000 and 48,989 in 1986. The continuous growth in the rural labor force inevitably increases the demand in grain production and socio-economic welfare. Reclaiming a new agricultural oasis is a reasonable choice based on this background.

The use of agricultural machinery can save labor force input in grain production and increase the production efficiency. Agricultural machinery input is particularly vital in labor shortage regions. However, for the sloping topography in HRB, the use of agricultural machinery has been limited in grain production. In addition, the rural labor force in HRB is also abundant, which reduces the use of agricultural machinery. The input of agricultural machinery per unit, thus, is not significantly driving the expansion of the agricultural oasis in HRB.

HRB is a typical arid region in China. One of the most vital limiting factors in grain production is the limited water resource. In the past three decades, the water resources in HRB have faced great challenges due to economic development, population growth and agricultural oasis expansion. Concerning the shortage in water resources, it is difficult to irrigate many newly reclaimed agricultural oases in HRB. In other words, the water resources in HRB cannot afford the continuous growth in HRB. More agricultural oases means a lower irrigated ratio. Thus, the irrigation ratio of agricultural oases is significantly positively correlated with the area of agricultural oases.

The grain yields per unit and ratio of grain sown have no significant influence on changes in the agricultural oasis. Due to the development of new agricultural techniques, the grain yield per unit in most regions in HRB has maintained an increasing trend during the period 1986-2011. However, most of the increase in grain yield was attributed to the high-quality agricultural oasis, which has an admirable irrigation facility and fertile soils. The grain yield per unit of newly reclaimed agricultural oases is usually low due to the poor natural conditions. Thus, the increase in grain yield did not significantly induce the expansion of the agricultural oasis.

In recent years, due to the comparative returns of production in grain and cash crops, the planting structure in HRB has experienced rapid changes (Deng and Zhao, 2014). Cash crops such as vegetables and fruits are planted more than ever. Although the planting of cash crops can obtain more returns, it usually needs better irrigation and soil conditions (e.g. vegetables) than grain. In addition, cash crops also need a great deal of field management and timely transaction, which requires a convenient transportation location. However, most of the expanded agricultural oasis is located on the fringe of the old agricultural oasis, which cannot satisfy the above-mentioned conditions. Thus the changes in planting structure did not induce the expansion of the agricultural oasis.

Annual temperature and precipitation were the two natural independent variables that we selected. They were both found to have significant positive influences on the expansion of the agricultural oasis in HRB. The annual precipitation in HRB showed a trending increase in HRB. Since HRB belongs to an arid region, the increase in precipitation benefits the crop plantation and increases the possibility of agricultural oasis reclamation. The influence of temperature change on grain production is complicated. The temperature increase in HRB will shorten the growing period of wheat and generate negative influences on the grain yield per unit without any adaptation measures (Tao et al., 2012). However, a temperature increase can extend the growing period of maize, and thus is a positive influence on grain yield of maize per unit (Xiao and Tao, 2014). In the past three decades, the plantation of maize in HRB experienced a rapid increase, which can be viewed as an adaptation of climate change. The temperature increase made the plantation of maize more suitable and induced the expansion of the agricultural oasis. 
Grain-for-green is the sole policy factor we selected for this paper. It was found to have no significant influence on changes in agricultural oasis expansion. Although the grain-for-green policy returned many sloping cultivated land to forestry or grassland, a great deal of grassland and forestry were reclaimed as an agricultural oasis simultaneously. The contradictory behavior weakens the effects of grain-for-green on agricultural oasis change.

\section{Discussion}

\subsection{Policy implications for controlling over-expansion of an agricultural oasis}

With future growth in the economy and population, the water resources in HRB will face greater challenges than ever (Deng et al., 2015, 2014). The agricultural oasis in HRB continuously expanded by $43.65 \%$ from 1986 to 2011 . Unlimited expansion of an agricultural oasis is not necessarily a positive thing for ecological security. Most of the population and agricultural oases in HRB were concentrated in the middle reaches. The agricultural oasis expansion also mainly occurred in this region. Due to the overexpansion of the population and agricultural oasis, the water consumption in middle reaches continuously increased, which significantly reduced the water yield entering the lower reaches. This kind of water consumption destroyed the natural balance between the desert and oasis and induced severe grassland degradation and desertification.

One of the most significant reasons for the over-expansion of the agricultural oasis in middle reaches is the insufficient transfer of rural labor forces, which has been identified as a significant positive factor driving agricultural oasis expansion in this paper. In HRB, the agriculture oasis accounted for more than $90 \%$ of the total water consumption. Transferring the rural labor force from agriculture to non-agriculture could effectively control the agricultural oasis expansion and save a great deal of water resources. The transfer of rural labor forces could be divided into two steps according to the complexity. The first step is that the rural labor force could be transferred from the planting industry to a non-planting industry. The planting industry is the largest water consumer in agriculture. Concentrating rural labor forces in the planting industry inevitably increases water consumption. The second step is that the rural labor force could be migrated from agriculture to nonagriculture, i.e. from rural areas to towns and urban areas. Only when this kind of migration occurs can the agricultural oasis expansion be controlled.

Policies of grain-for-green and grain subsidies should be appropriately modified. Grain-for-green aims to return deeply sloping cultivated land to grassland or forestry. In general, the policy should be able to restrain the irrational expansion of the agricultural oasis. However, it failed to achieve the aim. A possible reason could be that although a great deal of the sloping agricultural oasis was returned to grassland and forestry, much grassland and forestry were reclaimed as an agricultural oasis simultaneously. This phenomenon can be observed in the drastic conversions between agricultural oasis and grassland during the period 1986-2011. The grain subsidy policy was partly responsible for the policy failure of grain-for-green.

The grain subsidy policy gives farmers cash or material subsidies according to the actual grain-sown areas. The grain subsidy has continuously grown since its implementation. In HRB, the grain yield per unit is usually low, earning a minor net income from grain production. The enthusiasm of farmers for grain production is easily promoted by the grain subsidy. The grain subsidy also significantly influences the cultivation of the marginal agricultural oasis whose land rent is about zero. In general, the marginal agricultural oasis should be abandoned because of the poor returns. However, when the grain subsidy was provided, the marginal agricultural oasis became profitable, and thus induced the reclamation.

In order for grain-for-green to achieve success, the grain subsidy in HRB should be cancelled or at least be gradually reduced. In addition, the compensation for grain-for-green should be appropriately increased. In China, the slope of cultivated land that should be returned by grain-for-green is set at $15^{\circ}$ and higher. In consideration of the special situation in HRB, the slope standard of grain-for-green can be relaxed to $10^{\circ}$ or $12^{\circ}$. Finally, the reclamation of returned grassland and forestry by grain-for-green should be strictly prohibited.

\subsection{Comparisons of research results of this paper with other researches}

On the basis of two sets of $30 \mathrm{~m}$ resolution Landsat 5 and 7 images, Fu et al. (2014) mapped the land uses in the middle reaches of the HRB in 2000 and 2009. They found that the barren land and ice and snow in the middle reaches of HRB decreased by $15.66 \%$ and $88.44 \%$, respectively while agricultural land, range land, forest and water areas had expanded by $20.24 \%, 16.56 \%$, $5.91 \%$ and $144.27 \%$ respectively during $2000-2009$. According to our research, agricultural oasis, forestry areas, grassland, water areas, built-up areas and unused land changed $13.61 \%, 14.83 \%$, $0.23 \%,-3.08 \%, 45.63 \%$ and $-4.28 \%$ during $2000-2011$, respectively. The change trend of agricultural oasis, forestry areas, grassland and unused land are similar. However, the change trend of water areas is a little different. Water areas in middle reaches of HRB showed negative change trend in our research while that of Fu et al. (2014) present a negative change trend. In spite of the difference in research period, the unmatched land use classification of water areas could also attribute to the difference.

Lu et al. (2003) analyzed the landscape evolution in the middle reaches of Heihe River Basin from early 1980s to late 1990s. They found that farmland and water areas in middle reaches of HRB increased by $25.53 \%$ and $109.21 \%$ during $1985-1997$, respectively. Although the changes in water areas of Fu et al. (2014) is different from our researches, the water areas changes (increased by $109.21 \%$ during 1985-1997) assessed by Lu et al. (2003) is similar to our research (increased by $162.02 \%$ during $1986-2000$ ). In addition, the farmland expansion rate (25.53\%) of Lu et al. (2003) is also very similar to our research (24.41\%).

Many researches have qualitatively analyzed the driving forces of agricultural oasis expansion. Fu et al. (2014) found that the human activities have significantly changed the distribution and allocation of limited water resource in the basin, resulting in the expansion of oases. Zhou et al. (2015) believe that rapid agricultural and economic development leads to an expansion of constructed oases and considerable contraction of the oasis-desert transitional zone. According to the empirical analysis, most of the researches believed that human activities mostly accounted for the agricultural oasis expansion in HRB. However, using a panel data model we found that annual precipitation and annual temperature also significantly driving the expansion of agricultural oasis in HRB. In addition, we also quantitatively examined the influence of five socio-economic driving forces on agricultural oasis expansion. The influence of policy factor which is usually neglected by other researches was also quantitatively assessed in our research.

\section{Conclusions}

We examined the land use patterns and changes in the agricultural oasis in HRB. It was found that the expansion of the agricultural oasis and water areas are the main land-use changes in HRB 
during the period from 1986 to 2000, while the expansion of the agricultural oasis and built-up areas are the primary land-use changes in HRB from 2000 to 2011. The agricultural oasis in HRB expanded by $25.11 \%$ (annual rate of $1.79 \%$ ) and $14.82 \%$ (annual rate of $1.35 \%$ ) during the periods of 1986-2000 and 2000-2011. Most of the newly added agricultural oasis was converted from grassland and unused land. The agricultural oasis expanded mainly in the middle reaches of HRB, particularly in Shandan, Minle, Jinta, Jiuquan and the Zhangye municipal district.

Eight factors were selected to analyze the driving forces of agricultural oasis changes. According to the regression result of the panel data model, four factors were found having significant influences on agricultural oasis change. Rural labor forces, annual temperature and precipitation have positive effects on agricultural oasis changes, while the ratio of irrigated agricultural oases has negative effects on agricultural oasis changes. The agricultural oasis expansion in HRB is a result of the combined effects of human activity and climate change.

Irrigational expansion of the agricultural oasis will inevitably enlarge the water demand and limit the ecological sustainability in HRB. Therefore, effective measures should be adopted to control the over-expansion. Rural labor forces should be gradually guided to transfer from the planting industry to non-planting industry, and then to a non-agricultural industry. The policies of grain-forgreen and grain subsidies should be appropriately adjusted. The grain subsidy in HRB should be cancelled or gradually reduced. However, the compensation of grain-for-green should be increased. The slope standard of grain-for-green should be relaxed from $15^{\circ}$ to $10^{\circ}$ or $12^{\circ}$

\section{Conflicts of Interest}

The authors declare that there is no conflict of interests regarding the publication of this article.

\section{Acknowledgements}

This research was financially supported by the projects of the National Natural Science Foundation of China (Grant Nos. 91425303, 91325302 and 41501192).

\section{References}

Amuti, T., Luo, G., 2014. Analysis of land cover change and its driving forces in a desert oasis landscape of Xinjiang, northwest China. Solid Earth 5, 1071-1085.

Bai, J., Chen, X., Li, L., Luo, G., Yu, Q., 2014. Quantifying the contributions of agricultural oasis expansion, management practices and climate change to net primary production and evapotranspiration in croplands in arid northwest China. J. Arid Environ. 100, 31-41.

Chen, X.H., Duan, Z.H., Luo, T.F., 2014. Changes in soil quality in the critical area of desertification surrounding the Ejina Oasis, Northern China. Environ. Earth Sci. 72, 2643-2654.

Cheng, W.M., Zhou, C.H., Liu, H.J., Zhang, Y., Jiang, Y., Zhang, Y.C., Yao, Y.H., 2006. The oasis expansion and eco-environment change over the last 50 years in Manas River Valley, Xinjiang. Sci. China Ser. D 49, 163-175.

Deng, X.Z., Bai, X.M., 2014. Sustainable urbanization in Western China. Environment $56,12-24$.

Deng, X.Z., Huang, J.K., Rozelle, S., Uchida, E., 2006. Cultivated land conversion and potential agricultural productivity in China. Land Use Policy 23, 372-384.

Deng, X.Z., Huang, J.K., Rozelle, S., Zhang, J.P., Li, Z.H., 2015a. Impact of urbanization on cultivated land changes in China. Land Use Policy 45, 1-7.

Deng, X.Z., Jiang, Q.O., Su, H.B., Wu, F., 2010. Trace forest conversions in Northeast China with a 1-km area percentage data model. J. Appl. Remote Sens. 4.

Deng, X.Z., Shi, Q.L., Zhang, Q., Shi, C.C., Yin, F., 2015. Impacts of land use and land cover changes on surface energy and water balance in the Heihe River Basin of China, 2000-2010. Phys. Chem. Earth 79-82, 2-10.

Deng, X.Z., Zhang, F., Wang, Z., Li, X., Zhang, T., 2014. An extended input output table compiled for analyzing water demand and consumption at county level in China. Sustainability-Basel 6, 3301-3320.

Deng, X.Z., Zhao, C.H., 2014. Identification of water scarcity and providing solutions for adapting to climate changes in the Heihe River Basin of China. Adv. Meteorol. Article ID 279173.
Fu, L., Zhang, L.H., He, C.S., 2014. Analysis of agricultural land use change in the middle reach of the Heihe River Basin, Northwest China. Int. J. Environ. Res. Public Health 11, 2698-2712.

Guo, M., Yu, W.B., Ma, M.G., Li, X., 2008. Study on the oasis landscape fragmentation in northwestern China by using remote sensing data and GIS: a case study of Jinta oasis. Environ. Geol. 54, 629-636.

Hu, N.K., Li, X., 2014. Spatial distribution of an ancient agricultural oasis in Juyan, northwestern China. Front. Earth Sci.-Prc 8, 338-350.

Huai, B.J., Li, Z.Q., Wang, S.J., Sun, M.P., Zhou, P., Xiao, Y., 2014. RS analysis of glaciers change in the Heihe River Basin, Northwest China, during the recent decades. J. Geogr. Sci. 24, 993-1008.

Jia, B.Q., Zhang, Z.Q., Ci, L.J., Ren, Y.P., Pan, B.R., Zhang, Z., 2004. Oasis land-use dynamics and its influence on the oasis environment in Xinjiang, China. J. Arid Environ. 56, 11-26.

Jiang, P.H., Cheng, L., Li, M.C., Zhao, R.F., Duan, Y.W., 2015. Impacts of LUCC on soil properties in the riparian zones of desert oasis with remote sensing data: a case study of the middle Heihe River basin, China. Sci. Total Environ. 506, 259-271.

Jin, Q., Deng, X.Z., Wang, Z., Shi, C.C., Li, X., 2014. Analysis and projection of the relationship between industrial structure and land use structure in China Sustainability-Basel 6, 9343-9370.

Kenabatho, P.K., Parida, B.P., Moalafhi, D.B., 2012. The value of large-scale climate variables in climate change assessment: the case of Botswana's rainfall. Phys. Chem. Earth 50-52, 64-71.

King, C., Thomas, D.S.G., 2014. Monitoring environmental change and degradation in the irrigated oases of the Northern Sahara. J. Arid Environ. 103, 36-45.

Kusangaya, S., Warburton, M.L., van Garderen, E.A., Jewitt, G.P.W., 2014. Impacts of climate change on water resources in southern Africa: a review. Phys. Chem. Earth 67-69, 47-54.

Li, X.Y., Xiao, D.N., He, X.Y., Chen, W., Song, D.M., 2006. Dynamics of typical agricultural landscape and its relationship with water resource in inland Shiyang River watershed, Gansu Province, northwest China. Environ. Monit. Assess. 123, 199-217.

Ling, H.B., Xu, H.L., Fu, J.Y., Fan, Z.L., Xu, X.W., 2013. Suitable oasis scale in a typical continental river basin in an arid region of China: a case study of the Manas River Basin. Quatern. Int. 286, 116-125.

Liu, J.Y., Kuang, W.H., Zhang, Z.X., Xu, X.L., Qin, Y.W., Ning, J., Zhou, W.C., Zhang, S. W., Li, R.D., Yan, C.Z., Wu, S.X., Shi, X.Z., Jiang, N., Yu, D.S., Pan, X.Z., Chi, W.F. 2014. Spatiotemporal characteristics, patterns, and causes of land-use changes in China since the late 1980s. J. Geogr. Sci. 24, 195-210.

Liu, J.Y., Liu, M.L., Tian, H.Q., Zhuang, D.F., Zhang, Z.X., Zhang, W., Tang, X.M., Deng, X Z., 2005. Spatial and temporal patterns of China's cropland during 1990-2000 an analysis based on Landsat TM data. Remote Sens. Environ. 98, 442-456.

Liu, J.Y., Zhang, Z.X., Xu, X.L., Kuang, W.H., Zhou, W.C., Zhang, S.W., Li, R.D., Yan, C.Z. Yu, D.S., Wu, S.X., Nan, J., 2010a. Spatial patterns and driving forces of land use change in China during the early 21st century. J. Geogr. Sci. 20, 483-494.

Liu, W., Cao, S.K., Xi, H.Y., Feng, Q., 2010b. Land use history and status of land desertification in the Heihe River basin. Nat. Hazards 53, 273-290.

Lu, L., Li, X., Cheng, G.D., 2003. Landscape evolution in the middle Heihe River Basin of north-west China during the last decade. J. Arid Environ. 53, 395-408.

Ma, Y.F., Liu, S.M., Zhang, F., Zhou, J., Jia, Z.Z., Song, L.S., 2015. Estimations of regional surface energy fluxes over heterogeneous oasis-desert surfaces in the middle reaches of the Heihe River during HiWATER-MUSOEXE. IEEE Geosci. Remote Sens. Lett. 12, 671-675.

Misak, R.F., Baki, A.A.A., ElHakim, M.S., 1997. On the causes and control of the waterlogging phenomenon, Siwa Oasis, northern Western Desert, Egypt. J. Arid Environ. 37, 23-32.

Nutter, B., Hurni, H., Wiesmann, U., Ngana, J.O., 2013. Evaluating watershed service availability under future management and climate change scenarios in the Pangani Basin. Phys. Chem. Earth 61-62, 1-11.

Okin, G.S., Gillette, D.A., Herrick, J.E., 2006. Multi-scale controls on and consequences of aeolian processes in landscape change in arid and semi-arid environments. J. Arid Environ. 65, 253-275.

Pan, J.H., Li, T.Y., 2013. Extracting desertification from Landsat TM imagery based on spectral mixture analysis and Albedo-Vegetation feature space. Nat. Hazards 68, 915-927.

Seto, K.C., Kaufmann, R.K., 2003. Modeling the drivers of urban land use change in the Pearl River Delta, China: integrating remote sensing with socioeconomic data. Land Econ. 79, 106-121.

Siebert, S., Nagieb, M., Buerkert, A., 2007. Climate and irrigation water use of a mountain oasis in northern Oman. Agric. Water Manage. 89, 1-14.

Song, W., 2014. Decoupling cultivated land loss by construction occupation from economic growth in Beijing. Habitat Int. 43, 198-205.

Song, W., Liu, M.L., 2014. Assessment of decoupling between rural settlement area and rural population in China. Land Use Policy 39, 331-341.

Song, W., Pijanowski, B.C., 2014. The effects of China's cultivated land balance program on potential land productivity at a national scale. Appl. Geogr. 46, 158-170.

Su, Y.Z., Zhao, W.Z., Su, P.X., Zhang, Z.H., Wang, T., Ram, R., 2007. Ecological effects of desertification control and desertified land reclamation in an oasis-desert ecotone in an and region: a case study in Hexi Corridor, northwest China. Ecol. Eng. 29, 117-124.

Tao, F.L., Zhang, S.A., Zhang, Z., 2012. Spatiotemporal changes of wheat phenology in China under the effects of temperature, day length and cultivar thermal characteristics. Eur. J. Agron. 43, 201-212.

Wang, Y., Gao, J.X., Wang, J.S., Qiu, J., 2014. Value assessment of ecosystem services in nature reserves in Ningxia, China: a response to ecological restoration. PloS One 9. 
Wang, Y.G., Li, Y., Xiao, D.N., 2008. Catchment scale spatial variability of soil salt content in agricultural oasis, Northwest China. Environ. Geol. 56, 439-446.

Xiao, D.P., Tao, F.L., 2014. Contributions of cultivars, management and climate change to winter wheat yield in the North China Plain in the past three decades. Eur. J. Agron. 52, 112-122.

Xiao, S.C., Xiao, H.L., Peng, X.M., Song, X., 2015. Hydroclimate-driven changes in the landscape structure of the terminal lakes and wetlands of the China's Heihe River Basin. Environ. Monit. Assess. 187.

Xie, Y.C., Gong, J., Sun, P., Gou, X.H., 2014. Oasis dynamics change and its influence on landscape pattern on Jinta oasis in arid China from 1963a to 2010a: integration of multi-source satellite images. Int. J. Appl. Earth Obs. 33, 181-191.

Zhang, H., Wu, H.W., Zheng, Q.H., Yu, Y.H., 2003. A preliminary study of oasis evolution in the Tarim Basin, Xinjiang, China. J. Arid Environ. 55, 545-553.
Zhang, X.F., Zhang, L.H., He, C.S., Li, J.L., Jiang, Y.W., Ma, L.B., 2014. Quantifying the impacts of land use/land cover change on groundwater depletion in Northwestern China - a case study of the Dunhuang oasis. Agric. Water Manage. 146, 270-279.

Zhang, X.Y., Wang, X.M., Yan, P., 2008. Re-evaluating the impacts of human activity and environmental change on desertification in the Minqin Oasis, China. Environ. Geol. 55, 705-715.

Zhao, W.Z., Chang, X.L., 2014. The effect of hydrologic process changes on NDVI in the desert-oasis ecotone of the Hexi Corridor. Sci. China Earth Sci. 57, 3107-3117.

Zhou, S., Huang, Y.F., Yu, B.F., Wang, G.Q., 2015. Effects of human activities on the eco-environment in the middle Heihe River Basin based on extended environmental Kuznets curve model. Ecol. Eng. 76, 14-26. 